\title{
Facile Production of a Fenton-Like Photocatalyst by Two-Step Calcination with a Broad pH Adaptability
}

\author{
Siyang Ji, Yanling Yang, Xing Li, Hang Liu and Zhiwei Zhou *(i) \\ College of Architecture and Civil engineering, Beijing University of Technology, No.100 Xi Da Wang Road, \\ Chao Yang District, Beijing 100124, China; jsy_3021826@163.com (S.J.); yangyanling@bjut.edu.cn (Y.Y.); \\ lixing@bjut.edu.cn (X.L.); liuhang98596@163.com (H.L.) \\ * Correspondence: hubeizhouzhiwei@163.com; Tel.: +86-10-6739-1726
}

Received: 30 December 2019; Accepted: 31 March 2020; Published: 3 April 2020

\begin{abstract}
A novel heterogeneous Fenton-like photocatalyst, Fe-doped graphitic carbon nitride (Fe-g- $\mathrm{C}_{3} \mathrm{~N}_{4}$ ), was produced by facile two-step calcination method. This Fe-g- $\mathrm{C}_{3} \mathrm{~N}_{4}$ catalyzed rhodamine $\mathrm{B}$ degradation in the presence of $\mathrm{H}_{2} \mathrm{O}_{2}$ accompanied with visible light irradiation. transmission electron microscopy(TEM), x-ray diffraction (XRD), FT-IR, $x$-ray photoelectron spectroscopy (XPS), and photoluminescence fluorescent spectrometer (PL) characterization analysis methods were adopted to evaluate the physicochemical property of samples. It can be observed that the Fe-g- $\mathrm{C}_{3} \mathrm{~N}_{4}$ exhibited excellent photocatalytic Fenton-like activity at a wide $\mathrm{pH}$ range of 3-9, with rhodamine $\mathrm{B}(\mathrm{RhB})$ degradation efficiency up to $95.5 \%$ after irradiation for $45 \mathrm{~min}$ in the presence of $1.0 \mathrm{mM} \mathrm{H}_{2} \mathrm{O}_{2}$. Its high activity was ascribed to the formation of $\mathrm{Fe}-\mathrm{N}$ ligands in the triazine rings that accelerated electron movement driving the $\mathrm{Fe}(\mathrm{III}) / \mathrm{Fe}(\mathrm{II})$ redox cycle, and inhibited photo-generated electron hole re-combinations for continuous generation of reactive oxygen species by reactions between $\mathrm{Fe}(\mathrm{II})$ and $\mathrm{H}_{2} \mathrm{O}_{2}$. The main active oxygen species were hydroxyl radicals, followed by superoxide radicals and hole electrons. This produced catalyst of $\mathrm{Fe}-\mathrm{g}-\mathrm{C}_{3} \mathrm{~N}_{4}$ shows excellent reusability and stability, and can be a promising candidate for decontamination of wastewater.
\end{abstract}

Keywords: Fenton-like photocatalysis; graphitic carbon nitride; two-step calcination; composite materials

\section{Introduction}

Advanced oxidation process such as the Fenton reaction and photocatalysis has been extensively studied due to their high degradation activity toward the refractory organic pollutants in recent years [1]. The Fenton reaction has been proven to mineralize most of the organic pollutants [2]. However, the conventional homogeneous Fenton process suffers from the narrow $\mathrm{pH}$ range and large amounts of iron precipitation sludge [3]. To overcome these shortcomings, researchers worldwide have focused on the heterogeneous Fenton reaction that immobilizes iron species on the carriers such as clays [4], zeolites [5], and photocatalytic compounds. Furthermore, introducing the Fe-N ligands can effectively increase the $\mathrm{pH}$ range of the conventional Fenton reaction [6]. Ligands such as phthalocyanines and tetra-amido macrocyclic can form Fe-N ligands. For example, Gupta et al. used the Fe-TAML catalysts to degrade pentachlorophenol at a high $\mathrm{pH}$ of 10 [7]. Zhu et al. developed a $\mathrm{Fe}(\mathrm{II})$-phthalocyanine compound for the degradation of antibiotic carbamazepine [8]. The formation of $\mathrm{Fe}-\mathrm{N}$ ligands not only stabilizes the iron species, but also accelerates the $\mathrm{Fe}(\mathrm{III}) / \mathrm{Fe}(\mathrm{II})$ redox cycle, thus resulting in the ability to work at higher $\mathrm{pH}$ values [9].

Graphitic carbon nitride $\left(\mathrm{g}-\mathrm{C}_{3} \mathrm{~N}_{4}\right)$ is a polymer that combines superior photocatalytic properties with chemical stability [10]. It is easy to prepare through the one-step polymerization of cheap precursors of melamine, cyanoguanidine, and urea [11], and it contains structures with six nitrogen lone-pair electrons, which are ideal sites for chemical modification. However, the fast electron-hole recombination 
limited the application of one-step $\mathrm{g}-\mathrm{C}_{3} \mathrm{~N}_{4}$. Common modification methods are thermal oxidation exfoliation and surface modification with other ions [12]. On one hand, the two-step calcination (thermal oxidation exfoliation) could potentially improve the photocatalytic activity of one-step g- $\mathrm{C}_{3} \mathrm{~N}_{4}$ by increasing specific surface area and electron transport ability [13]. On the other hand, $g-\mathrm{C}_{3} \mathrm{~N}_{4}$ doping with metal atoms such as $\mathrm{Co}, \mathrm{Fe}, \mathrm{Cu}$, and $\mathrm{Pb}$ can enhance photocatalytic and oxygen-reduction activity. Wang et al. [14] used a one-step calcination method to prepare $\mathrm{CoS}_{2} / \mathrm{g}-\mathrm{C}_{3} \mathrm{~N}_{4}-\mathrm{rGO}$ for reduction of $\mathrm{Cr}$ (VI). Guo et al. [15] used one-step calcination method to synthesize a novel $\mathrm{Fe}_{2} \mathrm{O}_{3} @ g-\mathrm{C}_{3} \mathrm{~N}_{4}$ for the degradation of tetracycline. Dong et al. [16] developed $\mathrm{Cu}-\mathrm{g}-\mathrm{C}_{3} \mathrm{~N}_{4}$ by a modified impregnation method to degrade rhodamine $\mathrm{B}(\mathrm{RhB})$. Under visible light irradiation in the presence of $\mathrm{H}_{2} \mathrm{O}_{2}$, the Fenton-like photocatalysis of the above multifunctional compounds will take place, accompanying photoelectron-hole pairs that are generated and active radicals are produced that can degrade organic pollutants [17], meanwhile synergistic effects result from a combination with the Fenton reaction [18]. Specifically, photocatalysis can be combined with Fenton-like oxidation technology, on one hand, photo-generated electrons can promote the reduction of $\mathrm{Fe}^{3+}$; on the other hand, $\mathrm{H}_{2} \mathrm{O}_{2}$ in the Fenton reaction reacting with photo-generated electrons can reduce the electrons-hole recombination probability, thereby improving photocatalytic degradation efficiency $[19,20]$.

Herein, we synthesized a Fenton-like photocatalyst by two-step calcination that doped Fe upon $\mathrm{g}-\mathrm{C}_{3} \mathrm{~N}_{4}$. The $\mathrm{Fe}-\mathrm{g}-\mathrm{C}_{3} \mathrm{~N}_{4}$ catalysts were systematically characterized. Synergistic degradation of RhB by Fenton-like photocatalysis was investigated. The high $\mathrm{pH}$ adaptation from 3 to 9 was assessed, and the main active species and mechanism of reaction were clarified.

\section{Materials and Methods}

\subsection{Materials}

All chemical reagents used in these experiments were at least of analytical grade. Urea $\left(\mathrm{CH}_{4} \mathrm{~N}_{2} \mathrm{O}\right.$, $\geq 98.5 \%$ ), iron chloride hexahydrate $\left(\mathrm{FeCl}_{3} \cdot 6 \mathrm{H}_{2} \mathrm{O}, 99.0 \%\right)$, isopropyl alcohol (IPA, $\geq 99.5 \%$ ), ethylenediaminetetraacetic acid disodium salt (EDTA-2Na, 99.0\%), and RhB were purchased from Aladdin Industrial Corporation (Shanghai, China). All chemicals were used as received without further purification. Stock solutions were prepared with Milli-Q ultrapure water.

\subsection{Preparation of the Catalysts}

Urea and $\mathrm{FeCl}_{3} \bullet 7 \mathrm{H}_{2} \mathrm{O}$ were used for the preparation of the calcination of $\mathrm{g}-\mathrm{C}_{3} \mathrm{~N}_{4}$ and Fe-g- $\mathrm{C}_{3} \mathrm{~N}_{4}$. The two-step calcination of $\mathrm{g}-\mathrm{C}_{3} \mathrm{~N}_{4}$ was optimized according to the method described in a previous study with modifications [21]. One-step calcination (product with prefix ' $1{ }^{\text {st' }}$ ) was performed by heating $5 \mathrm{~g}$ urea with or without $0.105 \mathrm{~g} \mathrm{FeCl}{ }_{3} \bullet 7 \mathrm{H}_{2} \mathrm{O}$ to $550{ }^{\circ} \mathrm{C}$ at $5{ }^{\circ} \mathrm{C} / \mathrm{min}$ for $4 \mathrm{~h}$ in a muffle

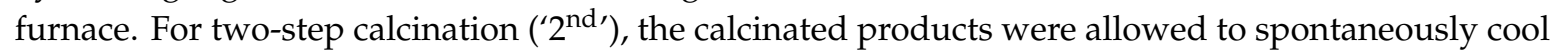
to room temperature, followed by a $2 \mathrm{~h}$-calcination step in a tube furnace at $520{ }^{\circ} \mathrm{C}\left(5^{\circ} \mathrm{C} / \mathrm{min}\right)$ in a nitrogen atmosphere (Figure 1a).

\subsection{Characterization}

The morphology of the products was characterized by field-emission scanning electron microscopy (FE-SEM, SU-8020, Hitachi, Tokyo, Japan) and high-resolution transmission electron microscopy (FEI, Tecnai G2 F20, USA). Their crystal structure was determined by x-ray diffraction (XRD-7000, Shimadzu, Kyoto, Japan) using $\mathrm{CuK} \alpha$ radiation with $2 \theta$ set from 10 to $80^{\circ}$. Fourier transform infrared (FTIR) was recorded with a NICOLET iS10 FTIR spectrometer. Surface chemical composition was analyzed by x-ray photoelectron spectroscopy (XPS, Thermo Fisher Scientific, Waltham, USA) with a monochromatic Al $\mathrm{K} \alpha$ source $(1486.6 \mathrm{eV})$. All binding energies were calibrated based on the C1s peak at $284.8 \mathrm{eV}$. The specific surface area was measured by nitrogen adsorption-desorption isotherms at $77 \mathrm{~K}$ using the Barret-Joyner-Hallender method (NOVA 3200e Sorptometer, Quantachrome, Florida, USA). The optical properties of the catalysts were analyzed by a photoluminescence fluorescent spectrometer (PL, 
FLS980, Livingston, Edinburgh) and an ultraviolet-visible diffuse reflectance spectrometer (UV-Vis DRS; 3600 plus, Shimadzu, Kyoto, Japan), respectively. Presence of free radicals was confirmed by electron paramagnetic resonance (EPR) (JES-FA200 JEOL, Tokyo, Japan) under visible light irradiation using 5,5-Dimethyl-1-pyrroline N-oxide (DMPO) as a trapping compound.

\subsection{Degradation Performance of the Catalysts}

The catalytic activity of the obtained catalysts were evaluated by $\mathrm{RhB}$ degradation efficiency at room temperature. For photocatalysis or Fenton-like photocatalysis, a 300W Xe lamp (CEAULIGHT, CEL-HXF300E7,Beijing, China) equipped with a $400 \mathrm{~nm}$ UV filter was used that emitted visible light $(400-780 \mathrm{~nm})$ at $280 \mathrm{~mW} / \mathrm{cm}^{2}$. RhB was used as the target pollutant at an initial concentration of $10 \mathrm{mg} / \mathrm{L}$ (filtered through $0.45-\mu \mathrm{m}$ acetate membranes prior to use).

For the photocatalysis reaction, as a typical process, $0.02 \mathrm{~g}$ of the catalyst $\left(\mathrm{g}-\mathrm{C}_{3} \mathrm{H}_{4}\right.$ and $\left.\mathrm{Fe}-\mathrm{g}-\mathrm{C}_{3} \mathrm{H}_{4}\right)$ was added into $100 \mathrm{~mL} \mathrm{RhB}$ solution $(10 \mathrm{mg} / \mathrm{L})$. Before irradiation, the suspension was stirred for $40 \mathrm{~min}$ in the dark to ensure light-independent adsorption-desorption equilibriums had been reached (presented in Supplementary Materials in Figure S1). Then, a $300 \mathrm{~W}$ Xe lamp equipped with a cut off filter $(>420 \mathrm{~nm})$ as a light source and placed $12 \mathrm{~cm}$ above the surface of the reaction solution was turned on.

For the Fenton-like photocatalysis reaction, under the same condition as the photocatalysis reaction, except that $1.0 \mathrm{mmol} / \mathrm{L} \mathrm{H}_{2} \mathrm{O}_{2}$ was added into the suspension before the irradiation, the doses of which were determined by our pre-experiments (Figure S2). A sample without any catalyst control was included as the control. At a specific time interval, $3 \mathrm{~mL}$ of the suspension solution was collected and filtered through a $0.22 \mu \mathrm{m}$ filter for measure by a UV-Vis Spectrophotometer (UV-2600, SOPTOP, China) at $554 \mathrm{~nm}$. When studying the influence of $\mathrm{pH}, 0.1 \mathrm{~mol} / \mathrm{L} \mathrm{HCl}$ and $\mathrm{NaOH}$ solutions were employed to adjust the initial $\mathrm{pH}$ value. The influence of $\mathrm{pH}$ on the treated solution during the reaction was not addressed, since the fluctuations of $\mathrm{pH}$ value were small $( \pm 0.2)$ [22].

The degradation kinetics of RhB in photocatalysis or the Fenton-like photocatalysis process were fitted based on a pseudo-first-order kinetic model (Equation (1)), where $\mathrm{C}_{0}(\mathrm{mg} / \mathrm{L})$ is the concentration of $\mathrm{RhB}$ after adsorption in dark $(\mathrm{mg} / \mathrm{L}), \mathrm{Ct}$ is the concentration at time $\mathrm{t}(\mathrm{min})$, and $\mathrm{k}\left(\mathrm{min}^{-1}\right)$ is the pseudo first-order rate constant.

$$
\ln C_{t} / C_{0}=-k t
$$

The stability and reusability of the synthesized catalysts were tested by repeating the Fenton-like photocatalysis experiment. For this, at the end of a photocatalytic experiment, the used $\mathrm{Fe}-\mathrm{g}-\mathrm{C}_{3} \mathrm{~N}_{4}$ was filtrated, washed, and dried before being used for the following test.

\section{Results}

\subsection{Characterization}

TEM images of the two calcination products were similar, but the material turned from flaxen-collared to brownish upon Fe doping (Figure $1 \mathrm{~b}, \mathrm{c}$ ). Element mapping of Fe-g- $\mathrm{C}_{3} \mathrm{~N}_{4}$ (Figure $1 \mathrm{~d}-\mathrm{g}$ ) confirmed the presence of Fe responsible for the color change. The Fe-signal overlapped with that of $\mathrm{N}$, indicating interactions between $\mathrm{Fe}$ and $\mathrm{N}$. One-step or two-step calcination of $\mathrm{Fe}-\mathrm{g}-\mathrm{C}_{3} \mathrm{~N}_{4}$ resulted in a nanosheet structure similar to that of $\mathrm{g}-\mathrm{C}_{3} \mathrm{~N}_{4}$ visible by SEM (Figure S2). The $\mathrm{S}_{\text {BET }}$ of $1^{\text {st }} \mathrm{g}-\mathrm{C}_{3} \mathrm{~N}_{4}$, $2^{\text {nd }} \mathrm{g}-\mathrm{C}_{3} \mathrm{~N}_{4}, 1^{\text {st }} \mathrm{Fe}-\mathrm{g}-\mathrm{C}_{3} \mathrm{~N}_{4}$ and $2^{\text {nd }} \mathrm{Fe}-\mathrm{g}-\mathrm{C}_{3} \mathrm{~N}_{4}$ was $56.78,78.54,45.61$, and $63.52 \mathrm{~m}^{2} / \mathrm{g}$, respectively, which implies that the two-step calcination can increase pore diameter and the BET specific surface area of both materials (Table S1). The higher surface area and larger pore diameter offer more active sites at the catalyst surface, which potentially enhance catalytic activity. 


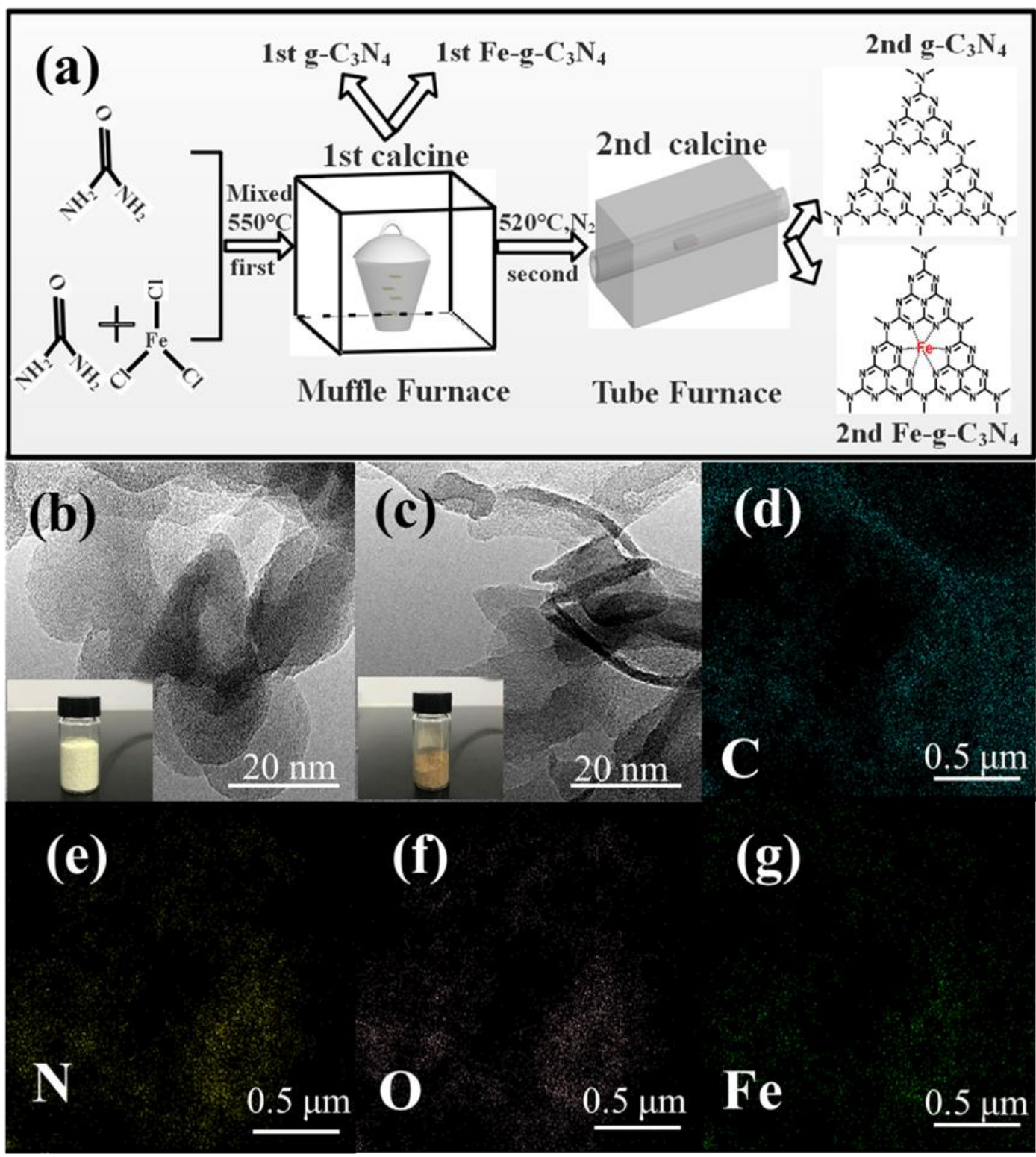

Figure 1. (a) Schematic of the one-step and two-step calcination process for the synthesis of $g-\mathrm{C}_{3} \mathrm{~N}_{4}$ and $\mathrm{Fe}-\mathrm{g}-\mathrm{C}_{3} \mathrm{~N}_{4}$, (b) TEM images of $2^{\text {nd }} \mathrm{g}-\mathrm{C}_{3} \mathrm{~N}_{4}$, and (c) $2^{\text {nd }} \mathrm{Fe}-\mathrm{g}-\mathrm{C}_{3} \mathrm{~N}_{4} ;(\mathbf{d}-\mathrm{g})$ element mapping of $2^{\text {nd }}$ Fe-g- $\mathrm{C}_{3} \mathrm{~N}_{4}$.

XRD patterns of materials by one-step and two-step calcination (Figure 2a) displayed a peak of the (002) plane around $27.5^{\circ}$, characteristic of a graphite-like structure (JCPDS No. 87-1526). The peak at $13.0^{\circ}$ was attributed to the crystal plane of (100) in-planar ordering of tri-s-triazine units [23], and this peak disappeared following Fe-doping, while the peak intensity for the (002) plane was significantly reduced, suggesting the absence of a rigid layer. There were no extra diffraction peaks observed for other phases such as Fe-related secondary phase or impurity, indicating Fe successfully doped into the $\mathrm{g}-\mathrm{C}_{3} \mathrm{~N}_{4}$ lattice. The FTIR spectra (Figure $2 \mathrm{~b}$ ) displayed characteristic bands in all samples for stretching vibration of $-\mathrm{NH}$ and $-\mathrm{NH}_{2}$ groups $\left(3000-3400 \mathrm{~cm}^{-1}\right), \mathrm{C}=\mathrm{N}$, and $\mathrm{C}-\mathrm{N}$ bonds $\left(1240-1640 \mathrm{~cm}^{-1}\right)$ [24], and triazine $\left(805 \mathrm{~cm}^{-1}\right)$. Iron peaks were not detected in $\mathrm{Fe}-\mathrm{g}-\mathrm{C}_{3} \mathrm{~N}_{4}$, suggesting that all $\mathrm{Fe}$ was doped into the $\mathrm{g}-\mathrm{C}_{3} \mathrm{~N}_{4}$. 

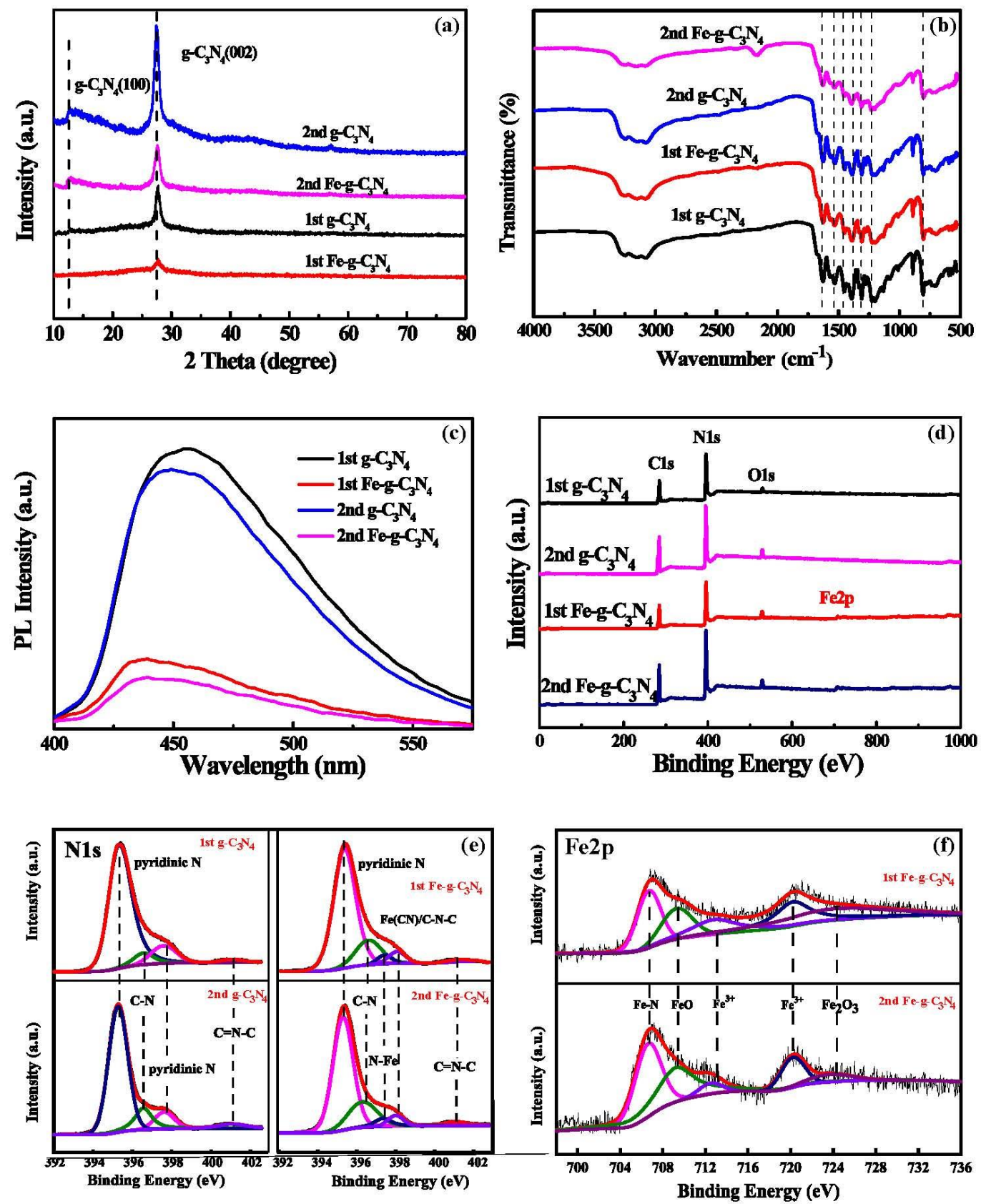

Figure 2. Characterization of one-and two-step $\mathrm{g}-\mathrm{C}_{3} \mathrm{~N}_{4}$ and $\mathrm{Fe}-\mathrm{g}-\mathrm{C}_{3} \mathrm{~N}_{4}$ by XRD (a); FTIR (b), photoluminescence (c); and XPS (d-f) with zooms of the N1s (e) and Fe2p (f) spectra.

As shown in Figure 2c, the PL emission of all the samples exhibited a primary emission peak around $450 \mathrm{~nm}$, which is consistent with the earlier reports [25-27]. We found that two-step calcination could reduce peak intensity. As Fe doping strongly reduced peak intensity, probably due to the transfer of photoelectrons to Fe through chemical bridging, resulting in inhibited recombination between photoelectrons and holes [28], this was of benefit to the photocatalytic activity of the catalyst activity of the catalyst. PL emission spectra are attributed to the band-gap emission in light of its absorption band edge, estimated by the UV-Vis DRS (Figure S4).

The surface chemical state was analyzed by XPS (Figure 2d), and the atomic content was calculated (Table S2). The proportion of Fe element was increased by two-step calcination compared to the one-step products. Peaks in the high-resolution of the N1s and Fe2p spectra were attributed to molecular components. The N1s spectrum of $\mathrm{g}-\mathrm{C}_{3} \mathrm{~N}_{4}$ in Figure 2e contains four peaks that were attributed 
to pyridinic $\mathrm{N}$ (395.3 and $397.6 \mathrm{eV})$ [29], $\mathrm{C}-\mathrm{N}(396.6 \mathrm{eV})$, and $\mathrm{C}=\mathrm{N}-\mathrm{C}(401.1 \mathrm{eV})$, respectively [30]. Fe-doping added peaks at 397.35 and $398.0 \mathrm{eV}$ corresponding to iron nitride $(\mathrm{N}-\mathrm{Fe})$ and $(\mathrm{Fe}-(\mathrm{CN}))$, respectively [31], accounting for 4.8 and $4.5 \%$ of the total N. The Fe2p spectrum in Figure $2 \mathrm{~g}$ illustrates that surface Fe represents Fe bonded with nitrogen $(\mathrm{Fe}-\mathrm{N})$ at $706.7 \mathrm{eV}, \mathrm{FeO}$ at $709.3 \mathrm{eV}$, and $\mathrm{Fe}_{2} \mathrm{O}_{3}$ at $724.0 \mathrm{eV}$, comprising $37.8 \%, 36.9 \%$, and $6.4 \%$, respectively [32,33]. No metallic Fe was detected on the surface of Fe-g- $\mathrm{C}_{3} \mathrm{~N}_{4}$, confirming that all Fe was completely doped into the $\mathrm{g}-\mathrm{C}_{3} \mathrm{~N}_{4}$ lattice and mainly in the form of $\mathrm{Fe}-\mathrm{N}$.

\subsection{Degradation Performance of the Catalysts}

The photocatalysis performance of the catalysts were tested under visible light irradiation. As exhibited in Figure 3a, the degradation efficiency of RhB by photolysis can be ignored in the absence of the catalyst, whereas the photocatalytic degradation efficiency of RhB by $2^{\text {nd }} \mathrm{g}_{-}-\mathrm{C}_{3} \mathrm{~N}_{4}$ was $51.7 \%$ within $45 \mathrm{~min}$, which was $13.2 \%$ higher than that of $1^{\text {st }} \mathrm{g}-\mathrm{C}_{3} \mathrm{~N}_{4}$. The photocatalytic activities were poor for both samples doped with $\mathrm{Fe}\left(1^{\text {st }} \mathrm{Fe}-\mathrm{g}-\mathrm{C}_{3} \mathrm{~N}_{4}\right.$ and $\left.2^{\text {nd }} \mathrm{Fe}-\mathrm{g}-\mathrm{C}_{3} \mathrm{~N}_{4}\right)$. The sequence of degradation effects from high to low was $2^{\text {nd }} \mathrm{g}-\mathrm{C}_{3} \mathrm{~N}_{4}, 1^{\text {st }} \mathrm{g}-\mathrm{C}_{3} \mathrm{~N}_{4}, 2^{\text {nd }} \mathrm{Fe}-\mathrm{g}-\mathrm{C}_{3} \mathrm{~N}_{4}$, and $1^{\text {st }} \mathrm{Fe}-\mathrm{g}-\mathrm{C}_{3} \mathrm{~N}_{4}$. From the fitted curve in Figure $3 b$, we found the degradation process of $\mathrm{RhB}$ conformed to the first-order kinetics model, and the calculated rate constant was $0.01446,0.01077,0.00436,0.00776 \mathrm{~min}^{-1}$, for $2^{\text {nd }} \mathrm{g}_{-} \mathrm{C}_{3} \mathrm{~N}_{4}$, $1^{\text {st }} \mathrm{g}-\mathrm{C}_{3} \mathrm{~N}_{4}, 2^{\text {nd }} \mathrm{Fe}-\mathrm{g}-\mathrm{C}_{3} \mathrm{~N}_{4}$, and $1^{\text {st }} \mathrm{Fe}-\mathrm{g}-\mathrm{C}_{3} \mathrm{~N}_{4}$, respectively. The photocatalysis performance of $2^{\text {nd }}$ $\mathrm{g}-\mathrm{C}_{3} \mathrm{~N}_{4}$ was the best, which was ascribed to the highest $\mathrm{S}_{\mathrm{BET}}\left(78.535 \mathrm{~m}^{2} / \mathrm{g}\right)$ and pore volume $(0.383 \mathrm{cc} / \mathrm{g})$ that had the most active sites. It can be concluded that two-step calcination improved properties in the degradation of dyes.
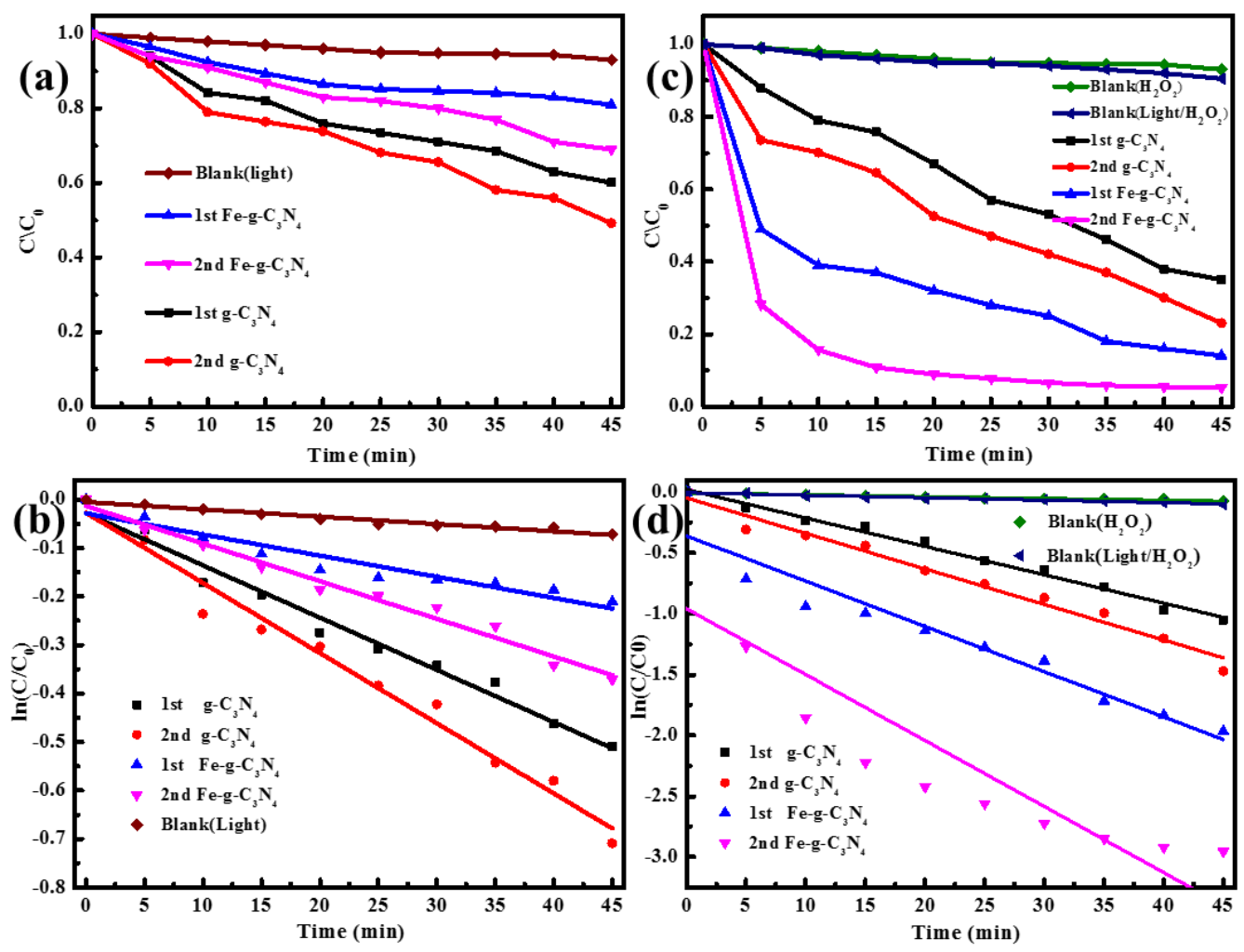

Figure 3. The photocatalysis performance and the pseudo-first-order kinetics fitted curves of RhB $(\mathbf{a}, \mathbf{b})$; and Fenton-like photocatalysis performance and the pseudo-first-order kinetics fitted curves of $\operatorname{RhB}(\mathbf{c}, \mathbf{d})$.

It can be seen from Figure $3 \mathrm{c}$ that the degradation efficiency of $\mathrm{RhB}$ with the addition of $\mathrm{H}_{2} \mathrm{O}_{2}$ only reached about $10 \%$ at $45 \mathrm{~min}$. The $\mathrm{H}_{2} \mathrm{O}_{2}$ under visible light without a photocatalyst could not improve 
RhB degradation efficiency, both confirming that $\mathrm{H}_{2} \mathrm{O}_{2}$ only or $\mathrm{H}_{2} \mathrm{O}_{2}$ with visible light irradiation could marginally degrade $\mathrm{RhB}$ [34]. The Fenton-like photocatalysis performance under visible light irradiation in the presence of $1.0 \mathrm{mM} \mathrm{H}_{2} \mathrm{O}_{2}$ was investigated. In the presence of $\mathrm{H}_{2} \mathrm{O}_{2}$, the degradation efficiency of RhB greatly increased after doped Fe ions (Figure 3c). The $2^{\text {nd }} \mathrm{Fe}-\mathrm{g}-\mathrm{C}_{3} \mathrm{~N}_{4}$ had the highest degradation efficiency, reaching up to $95.5 \%$ within $45 \mathrm{~min}$ ( $89 \%$ within $15 \mathrm{~min}$ ). In comparison, the degradation efficiency of RhB by $2^{\text {nd }} \mathrm{Fe}-\mathrm{g}-\mathrm{C}_{3} \mathrm{~N}_{4}$ under photocatalysis, Fenton-like, and Fenton-like photocatalysis within 45 min was $24.2 \%, 76.4 \%$, and $95.5 \%$, respectively.

In addition, it can be seen that the $2^{\text {nd }} \mathrm{Fe}-\mathrm{g}-\mathrm{C}_{3} \mathrm{~N}_{4}$ and $1^{\text {st }} \mathrm{Fe}-\mathrm{g}-\mathrm{C}_{3} \mathrm{~N}_{4}$ showed higher catalytic activity than that of the $2^{\text {nd }} \mathrm{g}-\mathrm{C}_{3} \mathrm{~N}_{4}$ and $1^{\text {st }} \mathrm{g}-\mathrm{C}_{3} \mathrm{~N}_{4}$. The rate constant of the $2^{\text {nd }} \mathrm{Fe}-\mathrm{g}-\mathrm{C}_{3} \mathrm{~N}_{4}$ (0.5424 $\left.\mathrm{min}^{-1}\right)$ was the highest among all the materials, which was about 1.46, 1.86, and 2.32 times higher that of the $1^{\text {st }} \mathrm{Fe}-\mathrm{g}-\mathrm{C}_{3} \mathrm{~N}_{4}\left(0.3722 \mathrm{~min}^{-1}\right), 2^{\text {nd }} \mathrm{g}-\mathrm{C}_{3} \mathrm{~N}_{4}\left(0.2921 \mathrm{~min}^{-1}\right)$, and $1^{\text {st }} \mathrm{g}-\mathrm{C}_{3} \mathrm{~N}_{4}$ $\left(0.2335 \mathrm{~min}^{-1}\right)$. This phenomenon was likely because iron doping can promote the production of active oxygen species [35].

The effect of $\mathrm{pH}$ value was tested with the $2^{\text {nd }} \mathrm{Fe}-\mathrm{g}-\mathrm{C}_{3} \mathrm{~N}_{4}$ only, in the presence of $\mathrm{H}_{2} \mathrm{O}_{2}$ (Figure 4). It shows that at the $\mathrm{pH}$ values of 3, 5, 7, and 9, the degradation efficiency of $\mathrm{RhB}$ was $96.0 \%, 95.2 \%$, $92.9 \%$, and $96.6 \%$. Although $\mathrm{RhB}$ degradation was more rapid at a $\mathrm{pH}$ of 3, degradation was still highly efficient at a $\mathrm{pH}$ of 5-9. The reason is that Fe doping into the $\mathrm{g}-\mathrm{C}_{3} \mathrm{~N}_{4}$ formed $\mathrm{Fe}-\mathrm{N}$ bonds, which promoted the migration and circulation of $\mathrm{Fe}$ ions and avoided the precipitation of iron salts during the Fenton-like reaction. This represents a major improvement compared to the classic Fenton reaction, which requires a $\mathrm{pH}$ of $2-4$. The $\mathrm{Fe}-\mathrm{N}$ ligand not only keeps the iron stable under different $\mathrm{pH}$ values, but also improves the redox properties [36].

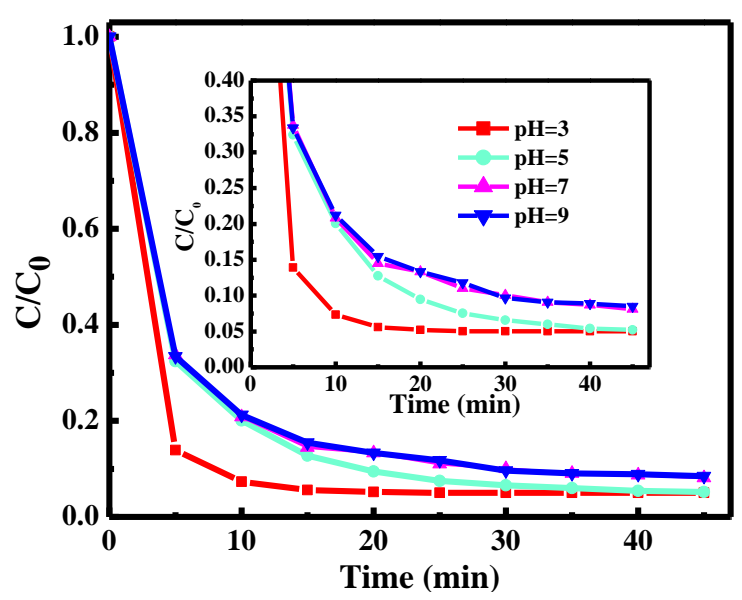

Figure 4. The different $\mathrm{pH}$ value of $\mathrm{RhB}$ degradation ( $2^{\text {nd }} \mathrm{Fe}-\mathrm{g}-\mathrm{C}_{3} \mathrm{~N}_{4}$ only). The solution $\mathrm{pH}$ was adjusted by $0.1 \mathrm{~mol} / \mathrm{L} \mathrm{HCl}$ or $\mathrm{NaOH}$, and the $\mathrm{pH}$ change of the treated solution was small during the reactions $( \pm 0.2)$.

We performed recycling tests by recovering the nanoparticles. As shown in Figure 5a, the remove efficiency of RhB by $2^{\text {nd }} \mathrm{Fe}-\mathrm{g}-\mathrm{C}_{3} \mathrm{~N}_{4}$ had no significant reduction after five cycles, with the degradation efficiency of $95.5 \%, 94.9 \%, 93.6 \%, 92.5 \%$, and $90.3 \%$, respectively. Furthermore, the fresh sample and that used after five times had similar XRD characteristic peaks (Figure 5b). The above results indicate the catalytic had an excellent Fenton-like photocatalytic reusability and stability. 

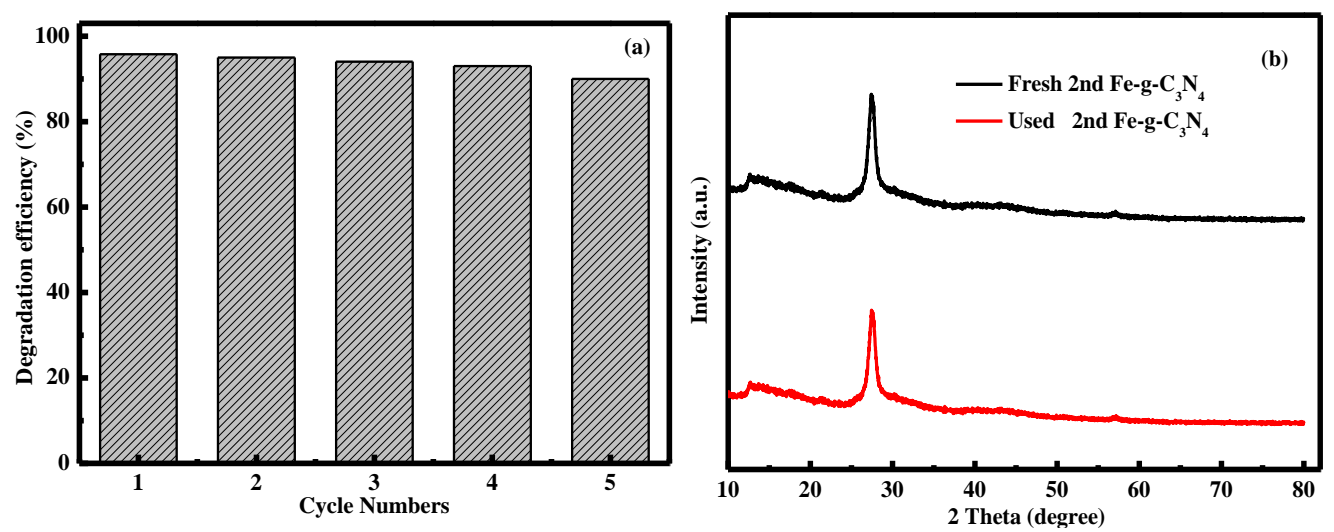

Figure 5. Reusability of the $2^{\text {nd }} \mathrm{Fe}-\mathrm{g}-\mathrm{C}_{3} \mathrm{~N}_{4}$ after five cycles (a); XRD patterns of the fresh and used $2^{\text {nd }}$ $\mathrm{Fe}-\mathrm{g}-\mathrm{C}_{3} \mathrm{~N}_{4}(\mathbf{b})$.

\subsection{Mechanism of Fenton-Like Photocatalytic Reaction}

The reactive species were detected under light and dark conditions by EPR, as shown in Figure $6 \mathrm{a}, \mathrm{b}$. Under visible light irradiation, the specific spectrum clearly appeared, which proved the production of $\bullet \mathrm{OH}$ and $\bullet \mathrm{O}_{2}{ }^{-}$during the catalytic process. In order to further prove the main reactive species, trapping tests were carried out. IPA $(1 \mathrm{mmol} / \mathrm{L})$ was used as a scavenger of $\bullet \mathrm{OH}$ in the reaction, EDTA-2Na ( $1 \mathrm{mmol} / \mathrm{L})$ and $\mathrm{N}_{2}$ were used as scavengers of holes and $\bullet \mathrm{O}_{2}$ [37], respectively. Compared with the residual $\mathrm{RhB}(\sim 4 \%)$ for 45 min without any scavenger, the residual $\mathrm{RhB}$ was 36.7, 8.1, and $17.2 \%$ with IPA, EDTA-2Na, and $\mathrm{N}_{2}$, respectively (Figure $6 \mathrm{c}$ ). This result indicates that $\bullet \mathrm{OH}$ was the primary reactive species, followed by $\bullet \mathrm{O}_{2}{ }^{-}$and hole electrons.
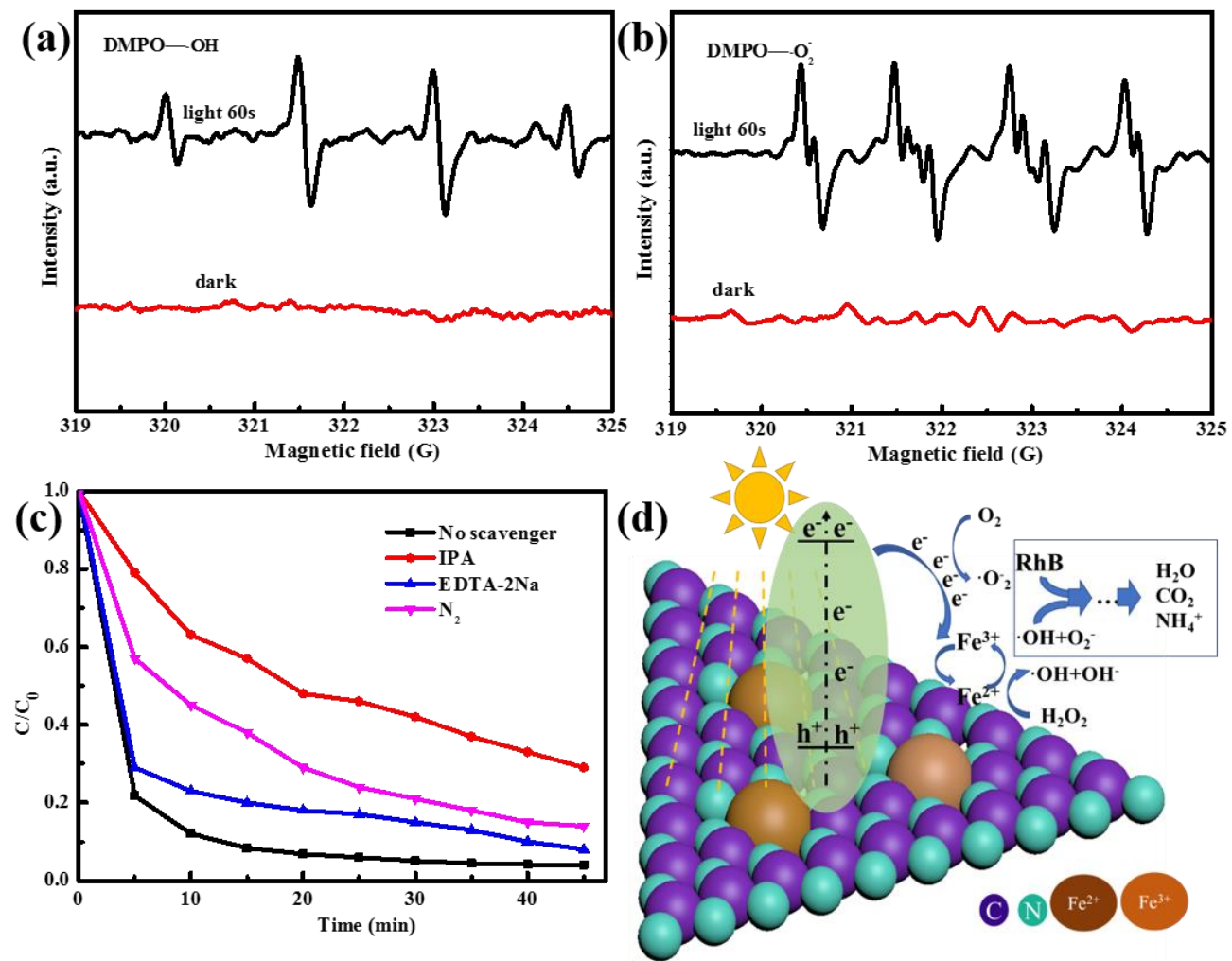

Figure 6. RhB degradation curves with different scavengers over $2^{\text {nd }} \mathrm{Fe}-\mathrm{g}-\mathrm{C}_{3} \mathrm{~N}_{4}$ (a), EPR spectra of $\mathrm{DMPO} / \bullet \mathrm{OH}(\mathbf{b}), \mathrm{EPR}$ spectra of $\mathrm{DMPO} / \bullet \mathrm{O}_{2}^{-}(\mathbf{c})$, and a schematic illustration of mechanism (d). 
Based on the above results and discussion, a tentative mechanism for $\mathrm{Fe}-\mathrm{g}-\mathrm{C}_{3} \mathrm{~N}_{4}$ dependent Fenton-like photocatalysis is shown in Figure $6 \mathrm{~d}$. Fe doped $\mathrm{g}-\mathrm{C}_{3} \mathrm{~N}_{4}$, not only led to a soluble and reactive form of iron (Fe(III) and $\mathrm{Fe}(\mathrm{II})$ ) at different $\mathrm{pH}$ values, but also the advantageously modified the redox properties by ligand-field effects [6]. When the Fe-g- $\mathrm{C}_{3} \mathrm{~N}_{4}$ was excited by visible light, the electrons shifted to the conduction band and the holes left in its valence band (Equation (2)). As the interfacial charge transfer effect, parts of the photo-excited electrons reduced Fe(III) into Fe(II) (Equation (3)) (Fe(III)/Fe(II), 0.77 V, vs. NHE) [38]. Normally, the transformation from Fe(III) to Fe(II) is the decisive step for the whole reaction, much lower than the other steps. Nevertheless, it is facilitated with $\mathrm{Fe}-\mathrm{N}$ ligands, thus created an excellent catalytic ability of $\mathrm{Fe}-\mathrm{g}-\mathrm{C}_{3} \mathrm{~N}_{4}$. Then, $\mathrm{Fe}(\mathrm{II})$ reacted with $\mathrm{H}_{2} \mathrm{O}_{2}$ to produce $\bullet \mathrm{OH}$ (Equation (4)), which oxidized RhB with a high efficiency. Moreover, the photo excited electron could also combine with the dissolved $\mathrm{O}_{2}$ in the solution to form $\bullet \mathrm{O}_{2}^{-}$(Equation (5)).

$$
\begin{aligned}
& \mathrm{hv}+ \rightarrow e^{-}+h^{+} \\
& \mathrm{Fe}^{3+}+e^{-} \rightarrow \mathrm{Fe}^{2+} \\
& \mathrm{Fe}^{2+}+\mathrm{H}_{2} \mathrm{O}_{2} \rightarrow \mathrm{Fe}^{3+}+\mathrm{OH}+\mathrm{OH}^{-} \\
& \mathrm{O}_{2}+\mathrm{e}^{-} \rightarrow \mathrm{O}_{2}^{-}
\end{aligned}
$$

\section{Conclusions}

In summary, the produced $\mathrm{Fe}-\mathrm{g}-\mathrm{C}_{3} \mathrm{~N}_{4}$ by two-step calcination was successfully synthesized. Secondary calcination can increase specific surface area and enhance Fenton-like photocatalysis efficiency. When iron was doped into the $\mathrm{g}-\mathrm{C}_{3} \mathrm{~N}_{4}$ framework, Fe-N bonds were formed, which could effectively reduce the electron-hole recombination rate and broaden the scope of reaction $\mathrm{pH}$ in the range of 3-9. The main active oxygen species were $\bullet \mathrm{OH}$, followed by $\bullet \mathrm{O}_{2}{ }^{-}$and hole electrons. This produced catalyst of $\mathrm{Fe}-\mathrm{g}-\mathrm{C}_{3} \mathrm{~N}_{4}$ shows excellent reusability and stability, and can be a promising candidate for dye degradation.

Supplementary Materials: The following are available online at http://www.mdpi.com/2079-4991/10/4/676/s1, Figure S1: The dark adsorption of RhB by catalysts, Figure S2: The effects of $2^{\text {nd }} \mathrm{Fe}-\mathrm{g}-\mathrm{C}_{3} \mathrm{~N}_{4}$ and $\mathrm{H}_{2} \mathrm{O}_{2}$ concentration on RhB degradation efficiency, Figure S3: SEM micrograph of $1^{\text {st }}-\mathrm{g}-\mathrm{C}_{3} \mathrm{~N}_{4}(\mathbf{a}), 1^{\text {st }} \mathrm{Fe}-\mathrm{g}-\mathrm{C}_{3} \mathrm{~N}_{4}(\mathbf{b}), 2^{\text {nd }} \mathrm{g}-\mathrm{C}_{3} \mathrm{~N}_{4}(\mathbf{c})$, and $2^{\text {nd }} \mathrm{Fe}-\mathrm{g}-\mathrm{C}_{3} \mathrm{~N}_{4}$, Figure S4: The UV-Vis diffuse reflectance spectra of $1^{\text {st }} \mathrm{g}-\mathrm{C}_{3} \mathrm{~N}_{4}, 1^{\text {st }}-\mathrm{Fe}-\mathrm{g}-\mathrm{C}_{3} \mathrm{~N}_{4}, 2^{\text {nd }} \mathrm{g}-\mathrm{C}_{3} \mathrm{~N}_{4}$, and $2^{\text {nd }} \mathrm{Fe}-\mathrm{g}-\mathrm{C}_{3} \mathrm{~N}_{4}$, Table S1: Structure parameters of the four samples, Table S2: Atomic content (at \%) from XPS analysis for samples.

Author Contributions: S.J. and H.L. were responsible for the experimental work, Y.Y. and X.L. supervised the laboratory work, Z.Z. led the research. All authors have read and agreed to the published version of the manuscript.

Funding: This work was realized with the financial support of the National Natural Science Foundation of China (51978006).

Acknowledgments: We give special thanks to Xiaohui Zhang from the CRRC Academy for their kind and valuable discussion and assistance during the paper writing.

Conflicts of Interest: The authors declare no conflicts of interest.

\section{References}

1. Zhou, L.; Wang, L.; Zhang, J.; Lei, J.; Liu, Y. Well-Dispersed $\mathrm{Fe}_{2} \mathrm{O}_{3}$ Nanoparticles on g- $\mathrm{C}_{3} \mathrm{~N}_{4}$ for Efficient and Stable Photo-Fenton Photocatalysis under Visible-Light Irradiation. Eur. J. Inorg. Chem. 2016, 2016, 5387-5392. [CrossRef]

2. Klamerth, N.; Malato, S.; Agüera, A.; Fernández-Alba, A.; Mailhot, G. Treatment of Municipal Wastewater Treatment Plant Effluents with Modified Photo-Fenton As a Tertiary Treatment for the Degradation of Micro Pollutants and Disinfection. Environ. Sci. Technol. 2012, 46, 2885-2892. [CrossRef] [PubMed]

3. Hsueh, C.; Huang, Y.; Wang, C.; Chen, C. Degradation of azo dyes using low iron concentration of Fenton and Fenton-like system. Chemosphere 2005, 58, 1409-1414. [CrossRef] [PubMed] 
4. Wan, D.; Li, W.; Wang, G.; Chen, K.; Lu, L.; Hu, Q. Adsorption and heterogeneous degradation of rhodamine B on the surface of magnetic bentonite material. Appl. Surf. Sci. 2015, 349, 988-996. [CrossRef]

5. Kuźniarska-Biernacka, I.; Raposo, M.M.M.; Baptista, R.M.F.; Parpot, P.; Biernacki, K.; De Magalhães, A.L.; Fonseca, A.; Neves, I. Highly efficient heterogeneous catalysts for phenol oxidation: Binuclear pyrrolyl-azine metal complexes encapsulated in NaY zeolite. Microporous Mesoporous Mater. 2016, 227, 272-280. [CrossRef]

6. Georgi, A.; Schierz, A.; Trommler, U.; Horwitz, C.; Collins, T.; Kopinke, F.-D. Humic acid modified Fenton reagent for enhancement of the working pH range. Appl. Catal. B Environ. 2007, 72, 26-36. [CrossRef]

7. Gupta, S.S.; Stadler, M.; Noser, C.A.; Ghosh, A.; Steinhoff, B.; Lenoir, D.; Horwitz, C.; Schramm, K.-W.; Collins, T.J. Rapid Total Destruction of Chlorophenols by Activated Hydrogen Peroxide. Science 2002, 296, 326-328. [CrossRef]

8. Zhu, Z.; Chen, Y.; Gu, Y.; Wu, F.; Lu, W.; Xu, T.; Chen, W. Catalytic degradation of recalcitrant pollutants by Fenton-like process using polyacrylonitrile-supported iron (II) phthalocyanine nanofibers: Intermediates and pathway. Water Res. 2016, 93, 296-305. [CrossRef]

9. Ensing, B.; Buda, F.; Baerends, E.J. Fenton-like chemistry in water: Oxidation catalysis by $\mathrm{Fe}(\mathrm{III})$ and $\mathrm{H}_{2} \mathrm{O}_{2}$. J. Phys. Chem. A 2003, 107, 5722-5731. [CrossRef]

10. Li, H.; Deng, P.; Hou, Y. Cobalt disulfide/graphitic carbon nitride as an efficient photocatalyst for hydrogen evolution reaction under visible light irradiation. Mater. Lett. 2018, 229, 217-220. [CrossRef]

11. Zheng, Y.; Liu, J.; Liang, J.; Jaroniec, M.; Qiao, S.-Z. Graphitic carbon nitride materials: Controllable synthesis and applications in fuel cells and photocatalysis. Energy Environ. Sci. 2012, 5, 6717-6731. [CrossRef]

12. Wang, M.; Yang, W.-H.; Wang, H.-H.; Chen, C.; Zhou, Z.-Y.; Sun, S.-G. Pyrolyzed Fe-N-C Composite as an Efficient Non-precious Metal Catalyst for Oxygen Reduction Reaction in Acidic Medium. ACS Catal. 2014, 4, 3928-3936. [CrossRef]

13. Niu, P.; Zhang, L.; Liu, G.; Cheng, H.-M. Graphene-Like Carbon Nitride Nanosheets for Improved Photocatalytic Activities. Adv. Funct. Mater. 2012, 22, 4763-4770. [CrossRef]

14. Haghighi, M.; Rahmani, F.; Dehghani, R.; Tehrani, A.M.; Miranzadeh, M.B. Photocatalytic reduction of Cr (VI) in aqueous solution over ZnO/ HZSM-5 nanocomposite: Optimization of ZnO loading and process conditions. Desalin. Water Treat. 2017, 58, 168-180. [CrossRef]

15. Guo, T.; Wang, K.; Zhang, G.; Wu, X. A novel $\alpha-\mathrm{Fe}_{2} \mathrm{O}_{3} @ g-\mathrm{C}_{3} \mathrm{~N}_{4}$ catalyst: Synthesis derived from Fe-based MOF and its superior photo-Fenton performance. Appl. Surf. Sci. 2019, 469, 331-339. [CrossRef]

16. Dong, Q.; Chen, Y.; Wang, L.; Ai, S.; Ding, H. Cu-modified alkalinized g- $\mathrm{C}_{3} \mathrm{~N}_{4}$ as photocatalytically assisted heterogeneous Fenton-like catalyst. Appl. Surf. Sci. 2017, 426, 1133-1140. [CrossRef]

17. Chatterjee, D.; Dasgupta, S. Visible light induced photocatalytic degradation of organic pollutants. J. Photochem. Photobiol. C Photochem. Rev. 2005, 6, 186-205. [CrossRef]

18. Guo, S.; Zhang, G.; Yu, J.C. Enhanced photo-Fenton degradation of rhodamine B using graphene oxide-amorphous FePO4 as effective and stable heterogeneous catalyst. J. Colloid Interface Sci. 2015, 448, 460-466. [CrossRef]

19. Doumic, L.I.; Soares, P.; Ayude, M.A.; Cassanello, M.; Boaventura, R.; Vilar, V.J. Enhancement of a solar photo-Fenton reaction by using ferrioxalate complexes for the treatment of a synthetic cotton-textile dyeing wastewater. Chem. Eng. J. 2015, 277, 86-96. [CrossRef]

20. Ortega-Liebana, M.C.; Sánchez-López, E.M.; Hidalgo-Carrillo, J.; Marinas, A.; Marinas, J.; Urbano, F.J. A comparative study of photocatalytic degradation of 3-chloropyridine under UV and solar light by homogeneous (photo-Fenton) and heterogeneous $\left(\mathrm{TiO}_{2}\right)$ photocatalysis. Appl. Catal. B Environ. 2012, 127, 316-322. [CrossRef]

21. Liu, J.; Liu, Y.; Liu, N.; Han, Y.; Zhang, X.; Huang, H.; Lifshitz, Y.; Lee, S.-T.; Zhong, J.; Kang, Z. Metal-free efficient photocatalyst for stable visible water splitting via a two-electron pathway. Science 2015, 347, 970-974. [CrossRef] [PubMed]

22. Xiong, Z.; Wang, Z.; Muthu, M.; Zhang, Y. Construction of an in-situ Fenton-like system based on a g- $\mathrm{C}_{3} \mathrm{~N}_{4}$ composite photocatalyst. J. Hazard. Mater. 2019, 373, 565-571. [CrossRef] [PubMed]

23. Liu, Q.; Zhang, J. Graphene Supported Co-g- $\mathrm{C}_{3} \mathrm{~N}_{4}$ as a Novel Metal-Macrocyclic Electrocatalyst for the Oxygen Reduction Reaction in Fuel Cells. Langmuir 2013, 29, 3821-3828. [CrossRef] [PubMed]

24. Xu, Y.; Zhang, L.; Yin, M.; Xie, D.; Chen, J.; Yin, J.; Fu, Y.; Zhao, P.; Zhong, H.; Zhao, Y.; et al. Ultrathin g-C $3 \mathrm{~N}_{4}$ films supported on Attapulgite nanofibers with enhanced photocatalytic performance. Appl. Surf. Sci. 2018, 440, 170-176. [CrossRef] 
25. Xu, J.; Li, Y.; Peng, S.; Lu, G.; Li, S. Eosin Y-sensitized graphitic carbon nitride fabricated by heating urea for visible light photocatalytic hydrogen evolution: The effect of the pyrolysis temperature of urea. Phys. Chem. Chem. Phys. 2013, 15, 7657. [CrossRef] [PubMed]

26. Li, X.; Zhang, J.; Shen, L.; Ma, Y.; Lei, W.; Cui, Q.; Zou, G. Preparation and characterization of graphitic carbon nitride through pyrolysis of melamine. Appl. Phys. A 2008, 94, 387-392. [CrossRef]

27. Wang, K.; Li, Q.; Liu, B.; Cheng, B.; Ho, W.; Yu, J. Sulfur-doped g- $\mathrm{C}_{3} \mathrm{~N}_{4}$ with enhanced photocatalytic $\mathrm{CO}_{2}$-reduction performance. Appl. Catal. B Environ. 2015, 176, 44-52. [CrossRef]

28. Hu, J.; Zhang, P.; An, W.; Liu, L.; Liang, Y.; Cui, W. In-situ Fe-doped g- $\mathrm{C}_{3} \mathrm{~N}_{4}$ heterogeneous catalyst via photocatalysis-Fenton reaction with enriched photocatalytic performance for removal of complex wastewater. Appl. Catal. B Environ. 2019, 245, 130-142. [CrossRef]

29. Leong, K.H.; Lim, P.F.; Sim, L.C.; Punia, V.; Pichiah, S. Improved solar light stimulated charge separation of g- $\mathrm{C}_{3} \mathrm{~N}_{4}$ through self-altering acidic treatment. Appl. Surf. Sci. 2018, 430, 355-361. [CrossRef]

30. Yatsimirskii, K.; Nemoshkalenko, V.; Nazarenko, Y.; Aleshin, V.; Zhilinskaya, V.; Tomashevsky, N. Use of $\mathrm{X}$-ray photoelectron and Mössbauer spectroscopies in the study of iron pentacyanide complexes. J. Electron Spectrosc. Relat. Phenom. 1977, 10, 239-245. [CrossRef]

31. Ma, J.Q.; Yang, Q.F.; Wen, Y.Z.; Liu, W.P. Fe-g- $\mathrm{C}_{3} \mathrm{~N}_{4}$ /graphitized mesoporous carbon composite as an effective Fenton-like catalyst in a wide $\mathrm{pH}$ range. Appl. Catal. B Environ. 2017, 201, 232-240. [CrossRef]

32. Maya, L.; Richards, H.L. Polymeric Cyanoborane, (CNBH2)n: Single Source for Chemical Vapor Deposition of Boron Nitride Films. J. Am. Ceram. Soc. 1991, 74, 406-409. [CrossRef]

33. Li, Z.; Kong, C.; Lu, G. Visible Photocatalytic Water Splitting and Photocatalytic Two-Electron Oxygen Formation over Cu- and Fe-Doped g- $\mathrm{C}_{3} \mathrm{~N}_{4}$. J. Phys. Chem. C 2015, 120, 56-63. [CrossRef]

34. Daneshvar, N.; Behnajady, M.A.; Mohammadi, M.K.A.; Dorraji, M.S.S. UV/ $\mathrm{H}_{2} \mathrm{O}_{2}$ treatment of Rhodamine B in aqueous solution: Influence of operational parameters and kinetic modeling. Desalination 2008, 230, 16-26. [CrossRef]

35. Chen, J.Y.; Xiao, X.Y.; Wang, Y.; Ye, Z.H. Fabrication of hierarchical sheet-on-sheet $\mathrm{WO}_{3} / \mathrm{g}-\mathrm{C}_{3} \mathrm{~N}_{4}$ composites with enhanced photocatalytic activity. J. Alloys Compd. 2019, 777, 325-334. [CrossRef]

36. Liu, W.; Ma, J.; Shen, C.; Wen, Y.; Liu, W. A pH-responsive and magnetically separable dynamic system for efficient removal of highly dilute antibiotics in water. Water Res. 2016, 90, 24-33. [CrossRef]

37. Alam, U.; Khan, A.; Raza, W.; Khan, A.; Bahnemann, D.W.; Muneer, M. Highly efficient Y and V co-doped $\mathrm{ZnO}$ photocatalyst with enhanced dye sensitized visible light photocatalytic activity. Catal. Today 2017, 284, 169-178. [CrossRef]

38. Liu, Q.; Guo, Y.R.; Chen, Z.H.; Zhang, Z.Z.; Fang, X.M. Constructing a novel ternary Fe(III)/graphene/g- $\mathrm{C}_{3} \mathrm{~N}_{4}$ composite photocatalyst with enhanced visible-light driven photocatalytic activity via interfacial charge transfer effect. Appl. Catal. B Environ. 2016, 183, 231-241. [CrossRef] 